WISSENSCHAFTSZENTRUM BERLIN FÜR SOZIALFORSCHUNG

SOCIAL SCIENCE RESEARCH CENTER BERLIN

\author{
Benny Geys * \\ Kai A. Konrad **
}

\title{
Federalism and Optimal Allocation \\ Across Levels of Governance
}

* WZB

** Max Planck Institute for Intellectual Property,

Competition and Tax Law and WZB

SP II $2010-09$

August 2010

Research Area

Markets and Politics

Research Professorship \& Project

"The Future of Fiscal Federalism"
Schwerpunkt

Märkte und Politik

Forschungsprofessur \& Projekt

"The Future of Fiscal Federalism" 
Benny Geys, Kai A. Konrad, Federalism and Optimal Allocation Across Levels of Governance, Discussion Paper SP II 2010 - 09, Wissenschaftszentrum Berlin, 2010.

Wissenschaftszentrum Berlin für Sozialforschung $\mathrm{gGmbH}$, Reichpietschufer 50, 10785 Berlin, Germany, Tel. (030) 25491 - 0 Internet: www.wzb.eu 


\section{ABSTRACT}

\section{Federalism and Optimal Allocation Across Levels of Governance}

by Benny Geys and Kai A. Konrad

Countries differ in their governmental architectures and in the rules that describe the allocation of tasks, rights and duties across the various levels of government. In this paper, we present a short and selective survey of the development of the theory of optimal allocation of rights and duties along the vertical dimension in federations. We thereby first discuss the multiple trade-offs brought forward in the literature; these make that an ideal allocation of actual tasks across levels of government may be difficult, if not impossible, to attain. Then we turn to the consequences of a sub-optimal allocation of tasks and discuss spillover effects, strategic interactions between jurisdictions and intergovernmental competition. Throughout the review, we highlight paths in need of further research such that, in time, we will have a more solid ground for policy advice.

\section{ZUSAMMENFASSUNG}

\section{Föderalismus und optimale Allokation über Regierungsebenen}

Staaten unterscheiden sich hinsichtlich ihres Regierungsaufbaus und ihren Verteilungsregeln von Aufgaben, Rechten und Pflichten über die verschiedenen Regierungsebenen hinweg. In diesem Artikel stellen wir eine kurze und selektive Übersicht über die Entwicklung der Theorie der optimalen Allokation von Rechten und Pflichten entlang der vertikalen Dimension in Staatenbünden vor. Wir diskutieren dabei zuerst die vielfachen, in der Literatur beschriebenen, Trade-offs. Diese führen dazu, dass eine ideale Verteilung der tatsächlichen Aufgaben schwierig, wenn nicht unmöglich zu erzielen ist. Als nächstes wenden wir uns den Konsequenzen der sub-optimalen Aufgabenverteilung zu und diskutieren externe Effekte, strategische Interaktionen zwischen den verschiedenen Gebietskörperschaften und zwischenstaatlichen Wettbewerb. Im gesamten Überblicksartikel stellen wir mögliche Pfade für notwendige weitere Forschung heraus, mit der für die Zukunft eine solide Grundlage für Politikberatung gelegt werden kann. 


\section{Introduction}

Countries differ in their governmental architectures and in the rules that describe the allocation of tasks, rights and duties across the various levels of government. Figure 1 displays the architecture of two (hypothetical) countries by way of illustration. Country $A$ on the left-hand side has two levels of government: a central government at the highest level and many small jurisdictions at the lower level. Country $B$ on the right-hand side has three layers of government: a central government at the highest level, two 'regional' governments representing an 'intermediate' level of government and several small jurisdictions at the third and lowest level. Clearly, these are only two possible constellations. Treisman (2000) analyses a large set of countries and finds government architectures involving between one (Singapore) and six layers of government (Russia). Many of these real-world government architectures are (significantly) more complicated than the ones depicted in Figure 1.

Figure 1: Two possible government architectures
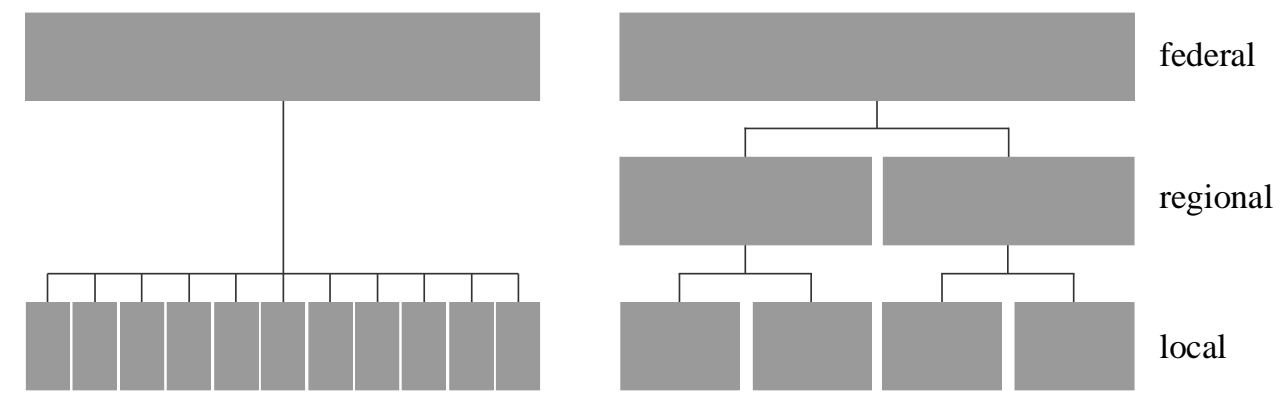

Moreover, countries' government architectures are not static, but subject to often substantial change. Such reforms are habitually the focus of intense political debates. 'Föderalismusreform' I (in 2006) and II (in 2008) in Germany and the debates about a further reorganization (or, more specifically, regionalization) of the government architecture in Belgium since the federal elections of June 2007 are illustrative. Similar debates exist also in many developing countries, and are high on the agenda of international organizations such as the World Bank or the IMF, which often act as consultants in the transformation process of developing countries. The development process of the European Union - with debates on the EU constitution, EU enlargement and the transfer of powers from the national to the EU level (e.g., concerning a common social, fiscal or foreign policy) - represents an important example of the fluidity of governmental architectures at the international level. Further, it illustrates that the nation state itself may be imbedded into larger governmental structure, with the European Union and international organizations being prominent examples (see, e.g., Zürn 2000, 2004). ${ }^{1}$

Interestingly, opinions concerning the instigating forces of these reform debates differ. Bolton and Roland (1997) and Alesina and Spolaore (2003) argue such debates are a consequence of increased globalization. Others, however, argue that globalization hinders decentralisation (Garrett and Rodden 2003). The theory of federalism needs to address both positive and normative questions regarding the choice of governmental architecture and the assignment of

1 In what follows we disregard important distinctions such as, for instance, between a federation of nations and a federal state, and focus on the intergovernmental issues that emerge within the same layer or between different layers of government in such structures and are common to both structures. 
tasks, rights, responsibilities etc. among different government levels. ${ }^{2}$ These include, but are not limited to, the assignment of a) rights to choose, collect, or spend different types of taxes, b) rights to issue debt and the responsibilities for repayment of debt within the federation, c) decision rights on public expenditures for goods that benefit only a subgroup within the federation (local public goods) and d) expenditures that affect all members of the federation (nationwide public goods). While these four examples are confined to the rights to tax and spend, similar choices concerning the optimal allocation of tasks obviously also apply to regulation of public issues more generally: e.g., education, environmental issues, cultural policy, defense, police and so on. Moreover, governance rules and the interdependencies and structure of democratic decision-making (division of power, election rules, etc.) must be chosen or designed. Still, for ease of exposition, we refer mainly to fiscal policies in what follows. The reason is that this is a theme most often returned to in the (fiscal) federalism literature. Nonetheless, it is important for the reader to keep in mind that the arguments presented are usually of a much more general nature and apply to the 'assignment problem' in a broad sense (and not just to the 'fiscal frame' within which they are presented).

We first start with a standard analysis of what is known as Oates' Decentralization Theorem (Oates 1972), which highlights an important trade-off in these allocation decisions. ${ }^{3}$ Even though this theorem does not provide the ultimate answers, it is useful as a frame of reference or point of departure. Also, it evened the ground for what Oates (2005) and Weingast (2006) call 'Second Generation Fiscal Federalism', which allowed analysis of aspects such as commitment power, time consistency issues and problems of information, as well as differences in political decision-making on different levels of government. Then, we discuss problems related to suboptimal task assignment (in section 3) and departures from the uniformity assumption made in Oates' (1972) analysis (in section 4). Finally, in section 5, we briefly elaborate on strategic effects of country's decentralization in the international sphere.

Overall, the short and necessarily selective survey offered in the present chapter illustrates that the theory of optimal allocation of rights and duties in federations cannot provide unambiguous one-size-fits-all recommendations. Especially the more recent contributions to this vast and fast-developing literature - based on insights derived from contract theory and political economy - clearly show that various trade-offs need to be considered simultaneously. As such, it is clear that the decentralization question is not resolved easily, suggesting that bold policy recommendations are unwarranted at this stage, and that more work is needed to develop a more solid ground for policy advice.

\section{The Decentralization Theorem}

The public sector is generally involved in a wide variety of tasks, including, for instance, social security, health care, defense, education and welfare benefits. Which level of government should take up a given task? In a very influential study, Oates (1972) provided an answer based on the observation that some public goods - such as national defense - benefit the entire population of a country, while others - such as local parks or street lighting mostly benefit the population of a very small region within a country (and might entail spillover effects). With this in mind, Oates argued that 'the provision of public services should be located at the lowest level of government encompassing [...] the relevant benefits and costs’ (Oates, 1999: 1122; see also Musgrave, 1959; Tullock, 1969; Breton and Scott,

\footnotetext{
2 The discussion on the division of tasks and power across different levels of government is known as the 'assignment problem' (e.g., Stigler 1957; Musgrave 1959; Oates 1972, 1999; McLure 1983; Inman and Rubinfeld 1997; Tanzi 2002).

3 See, for instance, Rosen (1988), Hindriks and Myles (2006), or Blankart (2008).
} 
1978, for early contributions to this debate and, for an overview, Inman and Rubinfeld, 1997). This idea became generally known as the Decentralization Theorem and underlies, for example, the principle of subsidiarity in the Maastricht Treaty of the European Union.

To see how Oates' 'solution' comes about, consider Figure 2 where we depict public provision of the per-capita quantity of a good $E$ in a country $G$. Country $G$ consists of two (equal-sized) regions $G_{1}$ and $G_{2}$. Provision of the good can either be taken up by the national government or by the governments of the two regions. Importantly, while the population of the country is split evenly across both regions and preferences for the publicly provided good are homogenous within each region, inhabitants of region $G_{2}$ have a stronger preference for the good than those in region $G_{1}$. To fix ideas, one could think of the good $E$ as education, and the population in region $G_{1}$ consisting of only elderly people while that in region $G_{2}$ is dominated by young families. Naturally, residents of region $G_{2}$ would, for any given price, demand more of the good than those of region $G_{1}$ (who might be more interested in social provisions for the elderly). This is reflected in the 'demand curve' for region $G_{2}$ (denoted $D_{G 2}$ ) lying further to the upper left corner compared to that of region $G_{1}$ (denoted $D_{G 1}$ ).

Figure 2: Graphical representation decentralization theorem

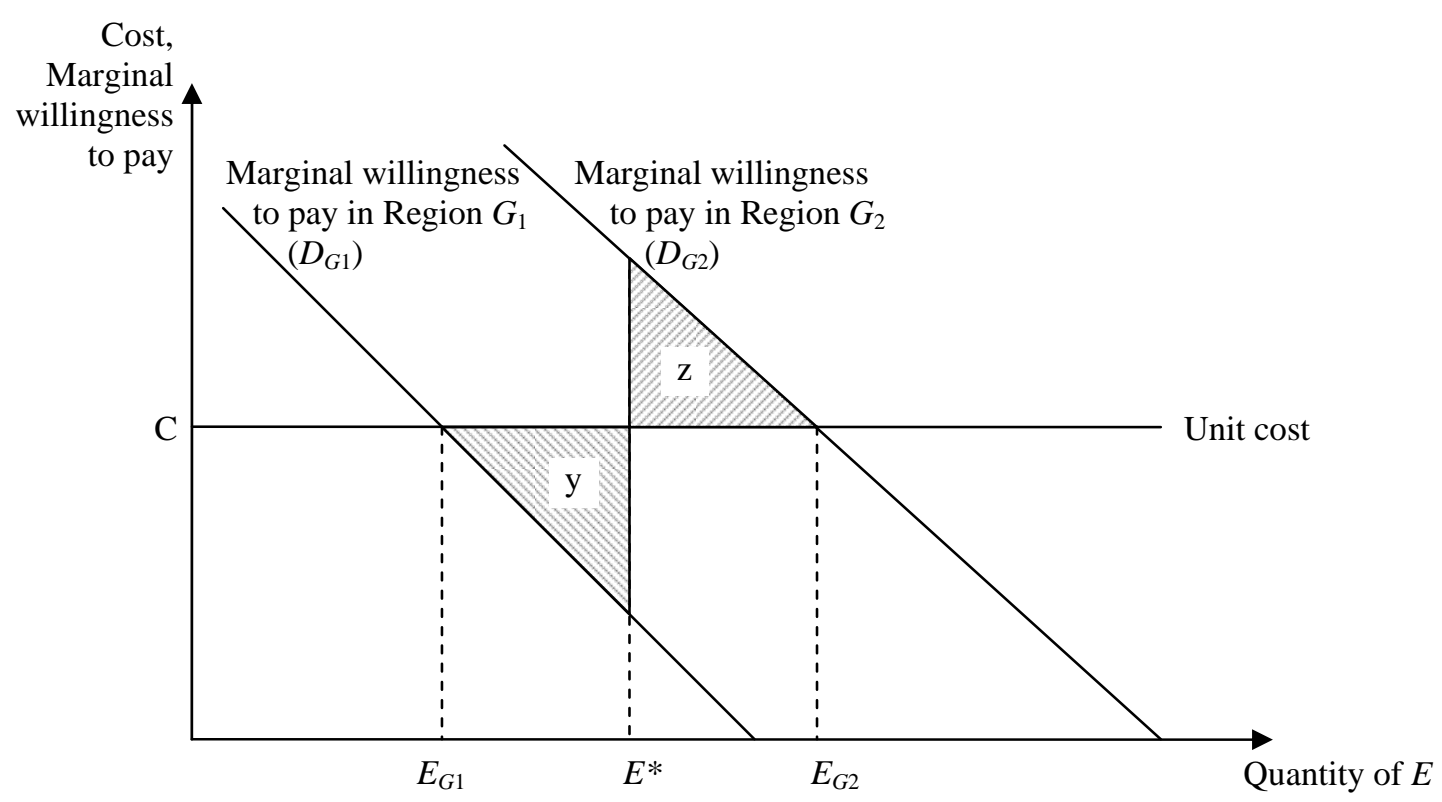

For simplicity, assume that the good can be produced at a constant cost $C$ per unit and per user (which is also the price charged to inhabitants, e.g., via taxes). At this price, region $G_{1}$ would demand quantity $E_{G 1}$, while region $G_{2}$ would prefer to consume $E_{G 2}$. Under central undifferentiated provision, however, each region would obtain $E^{*}$. This is clearly unsatisfactory for both regions. Region $G_{2}$ cannot fully exploit its consumer surplus, while region $G_{1}$ suffers a 'coercion loss' from being provided with too much of the good (or, more precisely, a good it cares too little for). These welfare losses are represented by triangles $z$ and $y$ respectively. These welfare losses become larger as the preferences of both regions diverge further. Under regional provision, on the other hand, such welfare losses do not occur as each region will supply the amount demanded by its population. Hence, when preferences differ across regions and benefits of a public good are local, provision should be 'located at the lowest level of government encompassing [...] the relevant benefits and costs' (Oates 1999: 1122) to avoid welfare losses. 
Through his analysis, Oates was the first to point at an important and intuitively evident tradeoff between i) interregional spillovers and a lack of full internalization on the local level on the one side, and ii) a tendency of the central government to be 'remote' from, and inattentive to, local needs on the other side. He thereby initiated a research program that studies questions deriving from this fundamental trade-off with the tools of modern incentive theory, contract theory and the theory of political economy. In what follows, we will go deeper into several questions that have received particular attention.

Still, before we do so, it should be pointed out that Oates' initial analysis clearly does not provide final answers. Indeed, the above line of argument rests strongly on the assumption that the central government is itself unable to differentiate the supply of the public good across both regions. This evidently is a very strong assumption. Nevertheless, in its absence, it becomes unclear whether centralized or decentralized provision is preferable from a welfare point of view. One early scholarly debate following the analyses of Tiebout (1956), Musgrave (1959), Tullock (1969), Oates (1972), Breton and Scott (1978) and Bewley (1981) therefore tried to generate deeper insights concerning the conditions under which decentralization may be beneficial - or not. Among the arguments discussed are information asymmetry and increasing returns.

Standard arguments raised when discussing decentralization often stress that state and local governments, being closer to the public, tend to be more responsive, accountable and aware of the preferences of their constituents than the central government (Oates 1999; Tanzi 2002). If the local government has information about local preferences, taxable income or other relevant variables which is not available to the central government, this can potentially cause principal-agent problems between the local and the central government. ${ }^{4}$ Decentralization of local public good supply and its financing may then be a natural design. ${ }^{5}$ This asymmetric information assumption has, however, been criticized on a deeper theoretical ground (see, e.g., Lockwood 2006: 38). If information is available at the local level, there typically exist information revelation mechanisms which a benevolent central government could use to obtain this information. In cases where the central government has sufficient enforcement power, it can even implement very inexpensive revelation mechanisms (e.g., the 'shoot the liar' mechanism), as it is typically true that several players at the local level have the relevant information.

A second argument concerns economies of scale in the production of a given public good and internalization of externalities. When local, small-scale production of the public good is much more expensive than central, large-scale production, it may be beneficial to organize provision of the public good at a higher level of government. Spillovers from local policies reinforce this point. Central governments are likely to internalize such inter-jurisdictional externalities, whereas local governments have no incentive to do so. Such spillovers can be important in policy areas as, e.g., police protection or pollution abatement. Hence, scale economies and spillovers appear to go against decentralization. Nonetheless, regions may

4 Contributions that follow this line of argument are, for instance, Bucovetsky, Marchand and Pestieau (1998), Cornes (2000), Bordignon, Manasse and Tabellini (2001), Huber and Runkel (2006) and Breuillé and GaryBobo (2007).

5 Nonetheless, complete information about citizens' preferences is unlikely even at the local level. In the theoretical model, revelation of preferences can be achieved by introducing mobility (cf. Tiebout 1956). People then sort themselves according to their preferences and all such information is revealed. Overall, however, the theoretical assumptions required for an efficient outcome are considerable (see, e.g., Bewley 1981). Moreover, in practice, lack of expertise or training as well as 'administrative weaknesses at the subnational level' may do much to counteract the benefits of decentralisation (Ter-Minassian 1997: 22; see also Geys and Moesen 2008a). 
cooperate and purchase the public good from the same supplier, which would be able to exhaust economies of scale. When such cooperation is feasible, decentralization may still be viable even under the presence of significant economies of scale.

\section{Losses from suboptimal task assignment}

While many theories have been developed from the normative point of view (i.e. arguing how tasks should ideally be allocated), an ideal allocation of actual tasks across levels of government is difficult, if not impossible, to attain. One reason is that the presiding allocation of tasks is often the result of historical incidents (or 'critical junctures') and path dependence (in the spirit of Pierson 2000; Mahoney 2000). It may be less than ideal (and all parties involved might even agree about this point), but it will be hard to change the existing configuration since no level of government is (usually) very willing to give up tasks and/or see its influence reduced. Related, central governments often are found to benefit from an 'attraction of power' known as Popitz's Law, in which they exploit their 'constitutional power [...] to take over state tax legislation' (Blankart 2000: 27; see also Vaubel 1994; Grossman and West 1994). This implies that even when an ideal allocation of powers could be reached at some point, this need not be an equilibrium that is easily maintained.

Another reason is that the trade-off between 'closeness' to local needs and potential for spillovers is difficult to resolve in practice. For example, some police tasks (such as local traffic regulation) can probably be safely assigned to local governments. However, other aspects of police enforcement (such as prevention of drug trafficking) are likely to entail considerable spillovers to other jurisdictions, which may ask for an assignment of this task to a higher level of government. Resolving such problems by the creation of two independent types of police may also not be optimal, as there may be economies of scope. ${ }^{6}$ Similarly, local measures against environmental pollution may improve the environment in neighboring jurisdictions. Medical, recreational, cultural or educational facilities can be used by citizens of neighbouring jurisdictions. Generous welfare programs may attract recipients from neighbouring jurisdictions. Finally, local taxes have externalities due to mobile tax bases. As shown by Mansoorian and Myers (1993), sometimes local politicians may internalize some of these externalities fully. When such interregional externalities are not, or only partially, accounted for, underinvestment in policies with positive externalities and overinvestment in policies with negative externalities may, but need not, occur in the absence of negotiations. A 'race to the bottom' may materialize (see, e.g., Brueckner 2000, 2003; Fredriksson and Millimet 2002). ${ }^{7}$

Spillover problems can be remedied by allocating the task to a central government, which internalizes the externalities and makes the optimal (collective) decision. Also, intergovernmental grants that are governed by the central government and distributed to the local governments, can remedy such problems. Such grants have indeed been recurrently

6 Related, the allocation of tasks that minimizes social welfare losses may entail a proliferation of local governments of different size for the various public goods with different regional outreach. Indeed, assuming that geographic spillovers of no two public goods are equal, the decentralization principle states that each public good should be provided by a different level of government (Mueller 2003). More intuitively, if everyone lives in his/her own region and decides individually on public good provision, there is no heterogeneity of preferences within each region. It follows from Figure 2 that there will likewise be no welfare losses in such a setting. While clearly taking the issue to its limit, it illustrates that optimal allocation of tasks is likely to be untenable in reality as it would induce enormous administration and coordination costs. As a result, allocation of tasks is - in reality - likely to be imperfect most of the time in most countries (or regions).

7 We return more extensively to such inter-governmental competition below. 
argued to help at internalizing spillover benefits from given policy decisions. However, their use is not entirely unproblematic. The design of these transfer schemes should be faced with due care (Inman 1999; Bird and Smart 2002). Matching grants, earmarked grants and block grants may affect jurisdictions' expenditures in different ways. Also, intergovernmental transfers may not invoke the same response from local politicians as increases in selfgenerated revenues (for instance, from local taxes). Theoretically, and using a median voter model, Bradford and Oates (1971) show that unconditional (or 'block') intergovernmental grants and private income should have equivalent effects on local public spending (since block grants only have an income effect). Empirical studies, however, fail to substantiate this prediction: grants often strongly increase public spending while private income mostly fails to do so (e.g., Gramlich and Galper 1973; Heyndels and Smolders 1994; Heyndels 2001; or, for a review, Hines and Thaler 1995). This phenomenon has become known as the 'flypaper effect' and indicates that the incentive structure of block grants needs to be carefully considered when introducing such schedules. ${ }^{8}$

Rather than for the internalisation of spillovers (or promoting spending on certain public goods), grants can also be used to increase fiscal equality between various governments. Providing grants through such fiscal equalization schemes is extensively employed in countries such as Canada and Germany and may 'limit tax competition among subnational governments [and] correct fiscal externalities’ (Bucovetsky and Smart 2006: 119). However, less positive, they may at the same time distort incentives for local governments to increase local economic growth (Weingast 2006) as well as increase government spending (Bucovetsky and Smart 2006). Grants can create incentives for local jurisdictions that may or may not be fully in line with those desired by the granting higher-level government. An efficient provision of services requires transfers to be designed such that 'those receiving them have a clear mandate, adequate resources, sufficient flexibility to make decisions and are accountable for results' (Bird and Smart 2002: 899). Given its importance, the optimal design of the financial structure within a federal state and the incentives this provides to localgovernment officials remains a hot topic of research to date.

Governments of local jurisdictions generally do not act in isolation, passively suffering from, or imposing externalities on others, but they interact strategically along many dimensions, including tax rates (for reviews, see Wilson 1999; Fuest, Huber and Mintz 2005), welfare benefit levels (for a review, see Brueckner 2003), environmental standards (e.g., Oates and Schwab 1988; Fredriksson and Millimet 2002), drug policy (e.g., Konrad 1994) and law enforcement (for a review, see Teichmann 2005). Also, the interdependence may derive from various sources (which are empirically hard to disentangle e.g., Brueckner 2003; Allers and Elhorst 2005; Werck, Heyndels and Geys 2008). One source is externalities among welfareoriented governments in strategic games. Second, in political competition, yardstick competition (cf. Shleifer 1985) may develop when voters use neighbouring jurisdictions to assess the quality of their own incumbents - and re-elect or substitute them accordingly (e.g.,

8 An alternative interpretation - although not unequivocally implied by the flypaper effect - is that the public sector suffers fewer inhibitions to spend grant revenues than funds obtained from private income. The latter interpretation suggests that revenues from intergovernmental grants might be spent less carefully (or more inefficiently) than revenues from, say, local taxation (see De Borger et al. 1994; De Borger and Kerstens 1996). The reason is that the cost of such inefficiencies falls on a much broader constituency (Silkman and Young 1982). Studies on public sector (in)efficiency have provided some empirical support for this view by uncovering a strong (and mostly negative) relation between grants and government efficiency (e.g., Silkman and Young 1982; De Borger et al. 1994; De Borger and Kerstens 1996; Grossman et al. 1999; Worthington 2000; Bishop and Brand 2003; Geys and Moesen, 2008b; Kalb, 2008). 
Salmon 1987; Besley and Case 1995; Bivand and Szymanski 1997). ${ }^{9}$ Finally, Ashworth and Heyndels (2000) argue that the use of neighbouring governments' policies as a reference point generates so-called transaction (dis)utility to voters (Thaler 1985). As this transaction utility is likely to also affect voting behaviour, the (rational) response of politicians is to follow each other's lead (e.g., Ashworth and Heyndels 2000; Geys 2006).

The existence of these spatial interactions between jurisdictions at the same level of government is by now generally acknowledged (for reviews, see Brueckner 2003; Revelli 2005). Whether or not this intergovernmental competition leads to more efficient governments is, however, a mute point of discussion (e.g., Belleflamme and Hindriks 2005; a similar discussion exists for the relation between the extent of expenditure decentralization, legal autonomy and efficiency; see, e.g., Barankay and Lockwood 2007). Sinn (1997), for example, argues that tax competition, and fiscal competition more generally, is dysfunctional between lower levels of government if the respective governments are assigned tasks that, from an allocation point of view, should be assigned to them. On the other hand, it has been shown that more/less efficient jurisdictions tend to have more/less efficient neighbours as well (see, e.g., Geys 2006; Revelli and Tovmo 2007). This suggests that efficiency is used as a competitive device between local governments, and tends to lead to better performance. A similar finding can be distilled from recent work by Revelli (2008), who shows that performance of British local jurisdictions improved strongly after (relative) performance ratings by the central government were made public.

It is important to mention at this point that most studies in this field concentrate on 'horizontal' competition between jurisdictions at the same level of government. In reality, however, interaction obviously also occurs between governments of different levels (i.e. vertically). Despite the real-world importance of such vertical interdependence, the effect of overlapping competencies across levels (i.e. in a vertical sense) has received relatively little emphasis in the foregoing federalism literature (e.g., Curry, 2006) - with some important exceptions. ${ }^{10}$ Solé-Ollé and Esteller-Moré (2001) and Devereux et al. (2007), for example, show that the vertical dimension of intergovernmental relations is important for excise taxation in the US (other empirical tests of vertical rather than horizontal tax competition include Besley and Rosen 1998; Revelli 2003; Andersson, Aronsson and Wikstrom 2004; Brülhart and Jametti 2006; Rizzo 2007). Kessing, Konrad and Kotsogiannis (2006, 2008) develop theoretical arguments for why vertical competition may deter foreign direct investment and Kessing, Konrad and Kotsogiannis (2007) find empirical evidence in line with these arguments. Also, Withers (1979) and Jenkins and Austen-Smith (1987) study the relation between public cultural spending by different levels of government (arguing that, say, federal arts outlays in a given jurisdiction affect state and local expenditures in that same jurisdiction). Interestingly, however, in the European integration literature in Political Science, a long-standing debate concerns the question whether European integration 'hollowed out' or strengthened the individual nation states within the Union (see, e.g., Milward, 1992; Marks, 1993; Moravcsik, 1994; Zürn, 1996).

9 Specifically, performance of politicians in other jurisdictions may be used to detect 'bad' types of politicians, even though they may try to mimic 'good' politicians. That is, federalism and the interjurisdictional comparison it allows the generation of useful (comparative) information that makes it easier to discern whether poor performance is due to bad luck or to bad behavior (even when exogenous shocks that affect politicians' performance are correlated).

10 For a discussion of vertical and horizontal tax competition, see Keen (1998), Keen and Kotsogiannis (2002) and Wrede $(1997,2000)$. 
Likewise, interactions in the form of so-called "multi-level games" (based on the initial contribution concerning two-level games by Putnam, 1988) have not been extensively dealt with in the federalism literature. In this respect, federalism scholarship diverges to an important extent from the extensive literature on "multi-level governance" (MLG), which analyses "contemporary structures in EU Europe as consisting of overlapping authorities and competing competencies” (Aalberts, 2004, 23). Future research would in our view certainly benefit from a further integration of insights from the MLG-literature with respect to the vertical 'coordination' or 'competition' between levels of jurisdictions into the federalism literature (which has predominantly concentrated on the horizontal dimension of competition between jurisdictions).

\section{Departures from 'uniformity by assumption'}

A cornerstone assumption for Oates' decentralization rule is uniformity of public good provision by the central government. Lockwood (2002: 313) suggests that this assumption is 'not consistent with the evidence in that, typically, spending by central governments is not uniform across regions in per capita terms' and in his (2006: 38) survey, he concludes that the uniformity assumption is 'clearly incorrect'. This may point to the fact that vertical decentralization involves more than the uniformity-versus-spillovers trade-off. In this section, we therefore briefly discuss findings from a recent branch of the political economy literature, which, strongly influenced by contract theory, considers different trade-offs which emerge from the institutional structure of governments.

Lockwood (2002), for example, assumes that centralized policy-making occurs through an assembly of delegates from all regions. The assembly decides about (possibly non-uniform) provision of public goods in the different regions, which is financed by an income tax that is uniform across regions. The legislative rules within the assembly are clearly important, and he discusses several modes of legislative rules. In doing so, a trade-off emerges between spillovers that occur in a decentralized assignment and the difficulties in the legislative process of centralized decision-making. Note that uniform treatment of all regions may occur in the equilibrium, but as an outcome, not by assumption. A consideration of the political decision making process on the regional level may also be important. Ihori and Yang (2008) apply a citizen candidate model for the election of the decision maker on the local level. They show that heterogeneity of capital ownership on the regional level may lead to strategic citizen candidate choices of higher capital income taxes than in a framework with politicians who maximize the welfare of the region. This can counterbalance the effects of tax competition.

Accountability of politicians becomes an important subject in a political economy framework. An interesting accountability problem may emerge even when a) all politicians are ex-ante identical, b) have incentives to behave selfishly, and c) the only mechanism for inducing them to perform well is the re-election mechanism. Seabright (1996) essentially exploits insights gained from the study of the organization of firms to address this problem. He starts from the observation that 'contracts' between voters and politicians are incomplete, giving politicians an incentive to behave opportunistically. The only way a voter can sanction a politician is by not re-electing him/her for a second period. In a decentralized country, each jurisdiction has an incumbent politician who decides about the policy in this jurisdiction. Under centralization, however, one politician makes many policy choices (i.e. one for each jurisdiction). As the politician needs only the votes from a majority of jurisdictions to be reelected, (s)he needs to behave accountably only to a majority of jurisdictions and can extort the remaining jurisdictions. The reason is that the latter are unable to exert any sanction given 
that they are in a minority position. One might call this a redundancy effect. Some jurisdictions and their votes become redundant to the politician. Instead of behaving accountably vis-à-vis these, the politician may take advantage of them.

Seabright's insight concerning the risk faced by multiple jurisdictions submitting to a centralized system with majoritarian re-election has instigated significant further research. Wrede (2006), for example, illustrates that a uniformity requirement may be a countermeasure to undesirable implications of the redundancy effect. Cai and Treisman (2008) consider governments' incentives for experimentation and innovation (see also Strumpf, 2002; Ashworth et al., 2006). With decentralized decision-making, each incumbent politician decides about whether to experiment in his jurisdiction, weighing the benefits and costs. Experimenting has a cost borne by the politician and the jurisdiction, but may have positive spillovers for other jurisdictions (as these may imitate successful experiments). As a result, there is a tendency for too little experimentation if this is decided decentrally. If, instead, a central politician chooses the number of different experiments and allocates these among various jurisdictions, the politician benefits from making use of successful experiments in other jurisdictions. Hence, the central politician is more able to internalize the positive spillovers from local experimentation. Also, the politician may be willing to run experiments in some jurisdictions (i.e. depart from uniformity of policies across jurisdictions), even if these experiments are unlikely to be successful and very unpopular among the voters in this jurisdiction, simply because the votes of this jurisdiction may be redundant, and not needed for his re-election.

\section{Strategic international effects of a country's decentralization}

So far, we have discussed the allocation of tasks or decision power within a country in isolation. However, countries, whether they are centralized or comprise of many vertical layers of government, interact with other countries. The allocation of tasks within a country has implications for a country's performance in the strategic interaction with other countries. In particular, a particular federal structure may yield commitment for this country in a strategic game with other countries, and depending on the nature of the strategic game, this commitment can be beneficial or detrimental.

Wilson and Janeba (2005) apply this idea to international tax competition. They show that a suitable delegation of tasks inside one country and decentralized tax financing of these tasks provides desirable commitment in this context. It has a strategic effect on the tax choices in other countries and may lead to an equilibrium with higher welfare. Kessing, Konrad and Kotsogiannis (2006, 2007, 2008) apply the same general logic to the competition between countries for foreign direct investment (FDI). They show that the allocation of taxation rights and policy decision-making along several vertical layers of government is disadvantageous for the country. For instance, if several levels of government jointly contribute to the subsidies offered to a potential foreign direct investor, then the governments from the different levels face a collective action problem. Also, when the governments from the different levels decide about taxing business activity, vertical tax externalities may lead to sub-optimally high taxes. These two effects also reinforce each other and jointly make the country less able to attract foreign direct investment in a competition with other countries. They also find strong empirical support for their theory.

Strategic effects of a different kind also emerge from centralizing or decentralizing decision rights for policies that have interregional and international spillovers. Among the examples that have been analysed are fiscal stabilization policy (Sørensen 1996), environmental policy 
(Buchholz, Haslbeck and Sandler 1998) and capital income tax policy (Konrad and Schjelderup 1999). Decentralization of decision-making for these policies in one country tends to change the country's total activity level. In an international context, this change in behavior is anticipated by other countries, and the governments in these other countries may, in response, adjust their own activity level. Consider, by way of example, activities against global warming - e.g., $\mathrm{CO}^{2}$-emission reductions - in Europe. Allocating emission reduction legislation to the European level may lead to substantial emission reductions in Europe (e.g., because such a coordinated solution may reduce free-rider effects). As a result, the need for emission reductions in non-European becomes lower. Anticipating the amount of emission reduction by European countries, the equilibrium reaction of non-European countries is to choose little emission reduction. On the other hand, allocation of decisions on emission reduction inside the EU to national or even regional governments will imply that none of these governments will engage very actively in reduction policy. The reason is that each will attempt to free-ride on others decisions, and invest too little in its own emission reduction. Anticipating that Europe will not reduce emissions by much, non-European countries may then feel that they need to reduce emissions more strongly.

These examples show that the international perspective must be added to gain a more complete picture of the optimal allocation of rights and duties in a federation. Decentralization or centralization decisions that might have desirable properties for the functioning of a country in isolation are likely to affect the interaction of the country as a whole with other countries in the international arena. These effects may go in the same direction as regards welfare, or may point into the opposite direction.

\section{Summary}

In this chapter we gave a short and selective survey of the development of the theory of optimal allocation of rights and duties along the vertical dimension in federations. The results showed that the message derived from this theory is not clear. Multiple trade-offs became visible, in particular in the more recent developments drawing on contract theory and political economy: e.g., between the potential for interregional spillovers and 'closeness to local needs or between spillovers in a decentralized assignment and the difficulties in the legislative process of centralized decision-making. These multiple trade-offs make that, in realty, an ideal allocation of actual tasks across levels of government might be difficult, if not impossible, to attain. Moreover, even if attained, scholars have pointed to strong forces which might make such a situation difficult to sustain over time.

Clearly, a sub-optimal allocation of tasks entails that there might be spillover effects across jurisdictions. While intergovernmental grants (governed by the central government and distributed to the local governments) may be used to remedy such spillover problems, the federalism literature has shown that such grants are not miracle solutions and involve significant problems of their own. Indeed, this 'remedy' requires careful planning and deliberation, and the optimal design of intergovernmental grants as well as the incentives they generate for local-government officials remains a hot topic of research to date.

If left unresolved, spillovers between local jurisdictions may engender various forms of strategic interaction or inter-governmental competition. To date, opinions vary concerning whether or not such competition leads to more or less efficient (local) governments - and more work is clearly needed on this topic. Also, most studies have thus far focused on 'horizontal' competition (i.e. between jurisdictions at the same level of government), while vertical interdependence has been relatively neglected. However, such vertical interactions are 
a reality and the federalism literature would do well to more extensively discuss their causes and consequences. One potential means to do so would be through integration of insights from the MLG-literature and the theory of "multi-level games" into the federalism literature.

With the advent of the "second generation" fiscal federalism literature, more attention has been awarded to incentives, goals and opportunities of local public officials rather than assuming them to be benevolent (as was the case in the early stages of the fiscal federalism literature). However, this literature is, in a sense, only in its infancy and more work is clearly needed on aspects such as commitment power, time consistency issues and problems of information. We also need to know more about, for example, the effects of (differences in) political decision-making processes on various levels of government, political accountability and the effects of (de)centralisation in one country on the strategic interactions between countries. Overall, the present survey therefore showed that the decentralization question is not resolved easily, suggesting that bold policy recommendations are unwarranted at this stage, and that more work is needed to develop a more solid ground for policy advice. 


\section{References}

Aalberts, T.E. (2004), The Future of Sovereignty in Multilevel Governance Europe - A Constructivist Reading, Journal of Common Market Studies, 42(1), 23-46.

Alesina, A. and E. Spolaore (2003), The Size of Nations, MIT Press: Cambridge.

Allers M.A. and J.P. Elhorst (2005), Tax Mimicking and Yardstick Competition among Local Governments in the Netherlands, International Tax and Public Finance, 12(4), 493-513.

Andersson, L., T. Aronsson and M. Wikstrom (2004), Testing for Vertical Externalities, International Tax and Public Finance, 11, 243-263.

Ashworth, J. and B. Heyndels (2000), Reference Point Effects in Local Taxation: It All Depends on How You Look at it, National Tax Journal, 53, 335-341.

Ashworth, J., B. Geys and B. Heyndels (2006), Determinants of Tax Innovation: The Case of Environmental Taxes in Flemish Municipalities, European Journal of Political Economy, 22(1), 223-247.

Barankay, I. and B. Lockwood (2007), Decentralization and the Productive Efficiency of Government: Evidence from Swiss Cantons, Journal of Public Economics, 91(5-6), 11971218.

Belleflamme, P. and J. Hindriks (2005), Yardstick Competition and Political Agency Problems, Social Choice and Welfare, 24(1), 155-169.

Besley, T. and A. Case (1995), Incumbent Behavior: Vote-Seeking, Tax Setting and Yardstick Competition, American Economic Review, 85(1), 25-45.

Besley, T. and H.S. Rosen (1998), Vertical Externalities in Tax Setting: Evidence from Gasoline and Cigarettes, Journal of Public Economics, 70, 383-398.

Bewley, T.F. (1981), A Critique of Tiebout Theory of Local Public-Expenditures, Econometrica, 49(3), 713-740.

Bird, R. and M. Smart (2002), Intergovernmental Fiscal Transfers: International Lessons for Developing Countries, World Development, 30(6), 899-912.

Bishop, P. and S. Brand (2003), The Efficiency of Museums: A Stochastic Frontier Production Function Approach, Applied Economics, 35(17), 1853-1858.

Bivand, R. and S. Szymanski (1997), Spatial Dependence through Local Yardstick Competition: Theory and Testing, Economics Letters, 55(2), 257-265.

Blankart, C.B. (2000), The Process of Government Centralization: A Constitutional View, Constitutional Political Economy, 11(1), 27-39.

Blankart, C.B. (2008), Öffentliche Finanzen in der Demokratie, $7^{\text {th }}$ edition, Vahlen: Munich.

Bolton, P. and G. Roland (1997), The Breakup of Nations: A Political-Economy Analysis, Quarterly Journal of Economics, 112(4), 1057-1090.

Bordignon, M., P. Manasse and G. Tabellini (2001), Optimal Regional Redistribution under Asymmetric Information, American Economic Review, 91(3), 709-723.

Bradford, D.F. and W.E. Oates (1971), The Analysis of Revenue Sharing in a New Approach to Collective Fiscal Decisions, Quarterly Journal of Economics, 85(3), 416-439.

Breton, A. and A. Scott (1978), The Economic Constitution of Federal States, Toronto University Press: Toronto. 
Breuillé, M.L. and R.J. Gary-Bobo (2007), Sharing Budgetary Austerity under Free Mobility and Asymmetric Information: An Optimal Regulation Approach to Fiscal Federalism, Journal of Public Economics, 91(5-6), 1177-1196.

Brueckner, J.K. (2000), A Tiebout/Tax-Competition Model, Journal of Public Economics, 77(2), 285-306.

Brueckner, J.K. (2003), Strategic Interaction among Governments: An Overview of Empirical Studies, International Regional Science Review, 26(2), 175-188.

Brülhart, M. and M. Jametti (2006), Vertical versus Horizontal Tax Externalities: an Empirical Test, Journal of Public Economics, 90, 2027-2062.

Buchholz, W., C. Haslbeck and T. Sandler (1998), When Does Partial Cooperation Pay? FinanzArchiv, 55(1), 1-20.

Bucovetsky, S., M. Marchand and P. Pestieau (1998), Tax Competition and Revelation of Preferences for Public Expenditure, Journal of Urban Economics, 44(3), 367-390.

Bucovetsky, S. and M. Smart (2006), The Efficiency Consequences of Local Revenue Equalization: Tax Competition and Tax Distortions, Journal of Public Economic Theory, 8(1), 119-144.

Cai, H. and D. Treisman (2008), Political Decentralization and Policy Experimentation, UCLA, unpublished manuscript.

Cornes, R. (2000), Local Public Goods, Risk Sharing, and Private Information in Federal Systems, Journal of Urban Economics, 47(1), 39-60.

Curry, D. (2006), Relations Revisited: A Nuanced Approach to Types of Multilevel Governance, CEU Political Science Journal, 5, 77-93.

De Borger, B. and K. Kerstens (1996), Cost Efficiency of Belgian Local Governments: A Comparative Analysis of FDH, DEA and Econometric Approaches, Regional Science and Urban Economics, 26(2), 145-170.

De Borger, B., K. Kerstens, W. Moesen and J. Vanneste (1994), Explaining Differences in Productive Efficiency: An Application to Belgian Municipalities, Public Choice, 80(3-4), 339-358.

Devereux, M., B. Lockwood and M. Redoano (2007), Horizontal and Vertical Indirect Tax Competition: Theory and Some Evidence from the USA, Journal of Public Economics, 91(3-4), 451-479.

Fredriksson, P.G. and D.L. Millimet (2002), Strategic Interaction and the Determination of Environmental Policy across US States, Journal of Urban Economics, 51(1), 101-122.

Fuest, C., B. Huber and J. Mintz (2005), Capital Mobility and Tax Competition: A Survey, Foundations and Trends in Microeconomics, 1(1), 1-62.

Garrett, G.M. and J.A. Rodden (2003), Globalization and Fiscal Decentralization, in: M. Kahler and D.A. Lake (eds.), Governance in a Global Economy. Political Authority in Transition, Princeton University Press: Princeton, pp. 87-109.

Geys, B. (2006), Looking across Borders: A Test of Spatial Policy Interdependence using Local Government Efficiency Ratings, Journal of Urban Economics, 60(3), 443-462.

Geys, B. and W. Moesen (2008a), Exploring Sources of Local Government Technical Inefficiency: Evidence from Flemish Municipalities, Public Finance and Management, forthcoming. 
Geys, B. and W. Moesen (2008b), Monitoring, Flypaper Effects and Local Government Technical (In)Efficiency: Evidence from Flemish Municipalities, Public Performance and Management Review, forthcoming.

Gramlich, E.M. and H. Galper (1973), State and Local Fiscal Behavior and Federal Grant Policy, Brookings Papers on Economic Activity, 1, 15-58.

Grossman, P.J., P. Mavros and R.W. Wassmer (1999), Public Sector Technical Inefficiency in Large US Cities, Journal of Urban Economics, 46(2), 278-299.

Grossman, P.J. and E.G. West (1994), Federalism and the Growth of Government Revisited, Public Choice, 79(1-2), 19-32.

Heyndels, B. (2001), Asymmetries in the Flypaper Effect: Empirical Evidence for the Flemish Municipalities, Applied Economics, 33(10), 1329-1334.

Heyndels, B. and C. Smolders (1994), Fiscal Illusion at the Local Level: Empirical Evidence for the Flemish Municipalities, Public Choice, 80(3-4), 325-338.

Hindriks, J. and G.D. Myles (2006), Intermediate Public Economics, MIT Press: Cambridge.

Hines, J.R. and R.H. Thaler (1995), Anomalies - The Flypaper Effect, Journal of Economic Perspectives, 9(4), 217-226.

Huber, B. and M. Runkel (2006), Optimal Design of Intergovernmental Grants under Asymmetric Information, International Tax and Public Finance, 13(1), 25-41.

Ihori, T. and C.C. Yang (2008), Interregional Tax Competition and Intraregional Political Competition: the Optimal Provision of Public Goods, University of Tokyo, unpublished manuscript.

Inman, R. (1999), On Designing Intergovernmental Transfers with an Application in the New South Africa, in: R. Schwab (ed.), Essays in Honor of Wallace Oates, Edgar Elger: Cheltenham.

Inman, R. and D.L. Rubinfeld (1997), Rethinking Federalism, Journal of Economic Perspectives, 11(4), 43-64.

Jenkins, S. and D. Austen-Smith (1987), Interdependent Decision-Making in Non-Profit Industries: A Simultaneous Equation Analysis of English Provincial Theatre, International Journal of Industrial Organisation, 5, 149-174.

Kalb, A. (2008), The Impact of Intergovernmental Grants on Cost Efficiency: Theory and Evidence from German Municipalities, presented at the 64th IIPF Meeting, Maastricht, August 2008.

Keen, M.J. (1998), Vertical Tax Externalities in the Theory of Fiscal Federalism, IMF Staff Papers, 45(3), 454-485.

Keen, M.J. and C. Kotsogiannis (2002), Does Federalism lead to Excessively High Taxes?, American Economic Review, 92(1), 363-370.

Kessing, S.G., K.A. Konrad and C. Kotsogiannis (2006), Federal Tax Autonomy and the Limit of Cooperation, Journal of Urban Economics, 59(2), 317-329.

Kessing, S.G., K.A. Konrad and C. Kotsogiannis (2007), Foreign Direct Investment and the Dark Side of Federalism, Economic Policy, 49, 5-70.

Kessing, S.G., K.A. Konrad and C. Kotsogiannis (2009), Federalism, Weak Institutions and the Competition for Foreign Direct Investment, International Tax and Public Finance, 16(1), 105-123. 
Konrad, K.A. (1994), Drug Policy and Federalism, Public Choice, 80(1-2), 55-68.

Konrad, K.A. and G. Schjelderup (1999), Fortress Building in Global Tax Competition, Journal of Urban Economics, 46(1), 156-167.

Lockwood, B. (2002), Distributive Politics and the Cost of Centralization, Review of Economic Studies, 69(2), 313-337.

Lockwood, B. (2006), The Political Economy of Decentralization, in: E. Ahmad and G. Brosio (eds.), Handbook of Fiscal Federalism, Edward Elgar: Cheltenham, pp. 33-60.

Mahoney, J. (2000), Path Dependence in Historical Sociology, Theory and Society, 29, 507548.

Marks, G. (1993), Structural policy and multilevel governance in the EC, in: A.W. Cafruny and G.G. Rosenthal (eds.), The State of the EC: The Maastricht Debates and Beyond, Harlow: Boulder.

Mansoorian, A. and G.M. Myers (1993), Attachment to Home and Efficient Purchases of Population in a Fiscal Externality Economy, Journal of Public Economics, 52(1), 117-132.

McLure, C.E. (1983), Tax Assignment in Federal Countries, Australian National University: Canberra.

Milward, A.S. (1992), The European Rescue of the Nation State, Routledge: London.

Moravcsik, A. (1994), Why the European Community strengthens the state: Domestic politics and international cooperation, Harvard University Press Working Paper Series, No. 52.

Mueller, D.C. (2003), Public Choice III, Cambridge University Press: Cambridge.

Musgrave, R.A. (1959), The Theory of Public Finance, McGraw-Hill: New York.

Oates, W.E. (1972), Fiscal Federalism, Harcourt Brace Jovanovich: New York.

Oates, W.E. (1999), An Essay on Fiscal Federalism, Journal of Economic Literature, 37(3), 1120-1149.

Oates, W.E. (2005), Toward a Second-Generation Theory of Fiscal Federalism, International Tax and Public Finance, 12(4), 349-373.

Oates, W.E. and R.M. Schwab (1988), Economic Competition among Jurisdictions Efficiency Enhancing or Distortion Inducing?, Journal of Public Economics, 35(3), 333354.

Pierson, P. (2000), Increasing Returns, Path Dependence, and the Study of Politics, American Political Science Review, 94(2), 251-267.

Putnam, R.D. (1988) Diplomacy and Domestic Politics: The Logic of Two-Level Games, International Organization, 42(3), 428-460.

Revelli, F. (2003), Reaction or Interaction? Spatial Process Identification in Multi-tiered Government Structures, Journal of Urban Economics, 53, 29-53.

Revelli, F. (2005), On Spatial Public Finance Empirics, International Tax and Public Finance, 12(4), 475-492.

Revelli, F. (2008), Spend More, Get More? An Inquiry into English Local Government Performance, University of Torino Department of Economics, WP 4/2008.

Revelli, F. and P. Tovmo (2007), Revealed Yardstick Competition: Local Government Efficiency Patterns in Norway, Journal of Urban Economics, 62(1), 121-134. 
Rizzo, L. (2007), Interaction between Vertical and Horizontal Tax Competition: Evidence and Some Theory, University of Ferrara, unpublished manuscript.

Rosen, H.S. (1988), Public Finance, $2^{\text {nd }}$ edition, Irwin: Homewood, Illinois.

Salmon, P.G. (1987), Decentralization as an Incentive Scheme, Oxford Review of Economic Policy, 3(2), 24-43.

Seabright, P. (1996), Accountability and Decentralization in Government: an Incomplete Contracts Model, European Economic Review, 40(1), 61-89.

Shleifer, A. (1985), A Theory of Yardstick Competition, Rand Journal of Economics, 16(3), 319-327.

Silkman, R. and D.R. Young (1982), X-efficiency and State Formula Grants, National Tax Journal, 35(3), 383-397.

Sinn, H.-W. (1997), The Selection Principle and Market Failure in Systems Competition, Journal of Public Economics, 66(2), 247-274.

Sørensen, J.R. (1996), Coordination of Fiscal Policy among a Subset of Countries, Scandinavian Journal of Economics, 98(1), 111-118.

Solé-Ollé, A. and A. Esteller-Moré (2001), Vertical Income Tax Externalities and Fiscal Interdependence: Evidence from the US, Regional Science and Urban Economics, 31(2-3), 242-272.

Stigler, G.J. (1957), Perfect Competition, Historically Contemplated, Journal of Political Economy, 65(1), 1-17.

Strumpf, K.S. (2002). Does Government Decentralization Increase or Decrease Innovation?, Journal of Public Economic Theory, 4, 207-241.

Tanzi, V. (2002), On Fiscal Federalism: Issues to Worry about, presented at IMF Conference on Fiscal Decentralization, Washington DC, November 2000.

Teichman, D. (2005), The Market for Criminal Justice: Federalism, Crime Control, and Jurisdictional Competition, Michigan Law Review, 103(7), 1831-1876.

Ter-Minassian, T. (1997), Fiscal Federalism in Theory and Practice, IMF: Washington.

Thaler, R.H. (1985), Mental Accounting and Consumer Choice, Marketing Science, 4(3), 199214.

Tiebout, C.M. (1956), A Pure Theory of Local Expenditures, Journal of Political Economy, 64(5), 416-424.

Treisman, D. (2000), Decentralization and the Quality of Government, UCLA, unpublished manuscript.

Tullock, G. (1969), Social Cost and Government Action, American Economic Review, 59(2), 189-197.

Vaubel, R. (1994), The Political Economy of Centralisation and the European Community, Public Choice, 81(1-2), 151-190.

Weingast, B.R. (2006), Second Generation Fiscal Federalism: Implications for Decentralized Democratic Governance and Economic Development, Hoover Institution, unpublished manuscript.

Werck, K., B. Heyndels and B. Geys (2008), The Impact of 'Central Places' on Spatial Spending Patterns: Evidence from Flemish Local Government Cultural Expenditures, Journal of Cultural Economics, 32(1), 35-58. 
Wilson, J.D. (1999), Theories of Tax Competition, National Tax Journal, 52(2), 269-304.

Wilson, J.D. and E. Janeba (2005), Decentralization and International Tax Competition, Journal of Public Economics, 89(7), 1211-1229.

Withers, G. (1979), Private Demand for Public Subsidies: An Econometric Study of Cultural Support in Australia. Journal of Cultural Economics, 3(1), 53-61.

Worthington, A.C. (2000), Cost Efficiency in Australian Local Government: A Comparative Analysis of Mathematical Programming and Econometric Approaches, Financial Accountability and Management, 16(3), 201-223.

Wrede, M. (1997), Tax Competition and Federalism: the Underprovision of Local Public Goods, FinanzArchiv, 54, 494-515.

Wrede, M. (2000), Shared Tax Sources and Public Expenditures, International Tax and Public Finance, 7(2), 163-175.

Wrede, M. (2006), Uniformity Requirement and Political Accountability, Journal of Economics, 89(2), 95-113.

Zürn, M. (1996), Über den Staat und die Demokratie im europäischen Mehrebenesystem, Politische Vierteljahresschrift, 37(1), 27-55.

Zürn, M. (2000), Democratic Governance Beyond the Nation-State: The EU and Other International Institutions, European Journal of International Relations, 6(2), 183-221.

Zürn, M. (2004), Global Governance and Legitimacy Problems, Government and Opposition, 39(2), 260-287. 